\title{
Revamping Technical and Vocational Education and Training in Niger Delta for Sustainable Development
}

\author{
Zite, BaridoolenuNgor ${ }^{1, *}$, Okwelle, P. Chijioke ${ }^{2}$ \\ Department of Vocational \& Technology Education, Rivers State University, Port Harcourt, Nigeria \\ *Corresponding Author:Zite, Baridoolenu Ngor, Department of Vocational \& Technology Education, \\ Rivers State University, Port Harcourt, Nigeria
}

\begin{abstract}
The study was aimed at investigating ways of revamping Technical and Vocational Education and Training (TVET) in Niger Delta for sustainable development. A descriptive survey design guided the study. A sample of 96TVET educators was randomly sampled for the study. Three research questions were answered in the study. The instrument used for data collection was a structured questionnaire validated by two TVET experts and its reliability coefficient of 0.79 was established using Pearson Product Moment Correlation (PPMC) coefficient reliability method. Data were analyzed with descriptive statistics of mean and standard deviation. It was found that provision of adequate modern facilities such as workshops, machines, library, personal computers; conducive classrooms will revamp TVET for sustainable development in federation. Based on the findings, it was recommended among others that ministries of education in all states $f$ the federation should improve the standard of infrastructural facilities in technical colleges in Nigeria, government and other stakeholders should make provisions for adequate funding of TVET in their annual budgets.
\end{abstract}

Keywords: Revamping, Facilities, Funding, Vocational and Technical Education, sustainable development

\section{INTRODUCTION}

The development of any nation hinges on the social and economic contributions of her citizens. Educational, vocational and educational training plays a major role at promoting community and national development (Oguntuyi, 2013). TVET facilitates the acquisition of applied skills and basic scientific knowledge. It is a planned programme of course and learning experiences that begin with the exploration of career options, supports basic, academic and life skills, and enables the achievement of high academic standards, leadership, preparation for industry and continuing education (CTE, 2009).

According to UNESCO(2001), TVET is a comprehensive term referring to those aspects of the educational process involving, in addition to general education, the study of technologies and related sciences and the acquisition of practical skills, attitudes, understanding and knowledge relating to occupations in various sectors of economic and social life. May (2007) says that the neglect of technical education in the area of adequate personnel, financial support and facilities to encourage vocational and technical education is robbing the nation of some contributions their graduates would have made to the economy. Ayodele (2006) identified the problem of irrelevant education that is bookish, theoretical and 'white collar job' oriented and lacks the characteristic of sustainability. In addition, government programmes are not designed to promote vocational and technical education. The level of infrastructural development and facilities provided by the government are affecting, to a very large extent, the level of skill acquisition in the country. The high rate of insecurity as exemplified in kidnapping, prostitution, arm robbery has relationship with unemployment and poverty among the people of Niger Delta.

Furthermore, Maclean (2011) asserts that TVET if well positioned could play multidimensional roles of stimulating economic growth, social development, improving conventional education, empowerment, wealth creation, poverty reduction and skills enhancement. In a nation with recurring incidences of youth restiveness, vocational and technical education is well suited to help youths and adults become self-dependent and self-reliant, while for those working in the industry, TVET is helpful in the areas of skills enhancement, mitigation of high 'job turnover and risks of obsolescence 
(Okolocha, 2012).Proper integration of TVET into the society by its educators enhances sustainable development among the Niger Deltans. Sustainable development has been defined by many in various ways. Adebola (2007) defines sustainable development as a kind of development that can be initiated and managed properly in such a way as to give attention to continuity and preservation as people explore an explicit available resources for the enlargement of their existence. Kundan in (Ugoh, 2008) describes sustainable development as a construct, which envision development as meeting the need of the present generation without compromising the needs of the future generation. These can only be achieved if the people of are expose to a revamped qualitative TVET programmes in Niger Delta region.

\subsection{Statement of Problem}

Vocational and Technical education is the hub of any economy of a nation just as the wheel rotates around the hub, the economic sector of Nigeria rotates around vocational and technical education considering the current socio-economic, scientific and technological development of Nigeria. Unfortunately, Nigeria does not seem to give vocational and technical education the attention it deserves. This appears to be one of the reasons for rising rate of unemployment and poverty in the society. The growing problem of unemployment in the country has contributed largely to the worsening problem of poverty among the populace. This is because the youth and graduates from tertiary institutions are not equipped with adequate skills that will enable them exploit the natural resources that abound in Nigeria. Nwanaka \& Amaehule (2011) also identify lack of awareness about vocational education programmes at various levels of school curricula as other shortcomings. In their view, it has taken the educationist working for the government more than twenty years to develop the national policy and the curriculum, yet the general public do not seem to understand the implication of TVET in the development of the economy. It is against this back drop that this paper is looking at ways of revamping vocational and technical education in Niger Delta for sustainable development.

\subsection{Purpose of the Study}

The main purpose of this study is to investigate ways of revamping vocational and technical education in Niger Delta for sustainable development. The specific objectives include:

i. To determine how provision of adequate modern facilities can aid in revamping the vocational and technical education programme in Niger Delta.

ii. To determine how funding can aid in revamping the vocational and technical education programme in Niger Delta.

iii. To find out how curriculum can aid in revamping the vocational and technical education programme in Niger Delta.

\subsection{Research Questions}

The study attempted to find answers to the following research questions:

i. To what extent can the provision of adequate modern facilities aid in revamping vocational and technical education programme in Niger Delta?

ii. To what extent can funding aid in revamping vocational and technical education programme in Niger Delta?

iii. To what extent can curriculum aid in revamping vocational and technical education programme in Niger Delta?

\section{MATERials AND Methods}

The study adopted a descriptive survey design and was conducted in tertiary institutions in Rivers State. The population of the study comprised 117 TVET educators in tertiary institutions offering VTE programmes in Rivers State. The institutions are Rivers State University, Port Harcourt, Ignatius Ajuru University of Education, Port Harcourt and Federal College of Education (Technical), Omoku. Simple random sampling technique was used in selecting 96 TVET educators. The instrument for data collection was a self-constructed questionnaire tagged "Revamping Vocational Technical Education for Sustainable Development in Niger Delta" (RVTESDND). The RVTESDND was divided into 
Revamping Technical and Vocational Education and Training in Niger Delta for Sustainable Development

three sections. Sections A, B and C were patterned after a4-point rating scale of Very High Extent, High Extent, Low Extent and Very Low Extent with numerical values of 4, 3, 2 and 1 respectively. Two experts in TVET validated the instrument. The internal consistency of the instrument was done through a test on 12 TVET educators twice at two weeks interval who were not part of the sample. A reliability value of 0.79 was established for the study through Pearson Product Moment Correlation Coefficients (PPMC). Out of 96 copies of the instrument that was distributed, 91 were completely filled and successfully retrieved which was used for analysis of the study. Mean and Standard Deviation were used to answer the research questions. To arrive at a decision on the research questions, real limits of numbers were used. Any item statement that had a mean value of 3.50-4.00 was regarded Very High Extent (VHE); 2.50-3.49 High Extent (HE); 1.50-2.49 Low Extent(LE); and 0.50-1.49 as Very Low Extent(VLE).The standard deviation was used to determine the homogeneity or otherwise of the respondents' mean ratings. Statistical Package for Social Science (SPSS) was used for data analysis.

\section{Results}

Research Question1: To what extent can the provision of adequate modern facilities aid in revamping vocational and technical education programme in Niger Delta?

Table1.Mean Response on the Provision of Adequate Facilities in Revamping TVET

\begin{tabular}{|l|l|l|l|l|}
\hline S/NO & Item Statement & Mean & S.D & Decision \\
\hline 1 & Provision of e-library in TVET institutions & 3.12 & 1.05 & HE \\
\hline 2 & Availability of personal computers & 3.77 & 0.97 & VHE \\
\hline 3 & Provision of internet services for TVET lecturers & 3.25 & 0.74 & HE \\
\hline 4 & Availability of classroom space & 3.58 & 1.05 & VHE \\
\hline 5 & Provision of internet services for TVET students & 3.94 & 0.62 & VHE \\
\hline 6 & Rehabilitation of workshops & 3.30 & 0.78 & HE \\
\hline 7 & Learning with machines & 3.66 & 0.59 & VHE \\
\hline & Average Mean/SD & $\mathbf{3 . 5 2}$ & $\mathbf{0 . 8 3}$ & VHE \\
\hline
\end{tabular}

Source: Researchers Field Work; 2018

Table 1 revealed that the provision of adequate modern facilities were to a High Extent on items 1, 3 and 6 while items 2, 4, 5 and 7 were to Very High Extent. The average score indicated that provision of adequate modern facilities was at Very High Extent (VHE) with an average mean of 3.52.The standard deviations for the items are within the range of $0.59-1.05$, signifying that the respondents were homogeneous in their opinions.

Research Question2: To what extent will funding aid in revamping vocational and technical education programme in Niger Delta?

Table2.Mean Response on the Provision of Fund in Revamping TVET

\begin{tabular}{|l|l|l|l|l|}
\hline S/NO & Item Statement & Mean & S.D & Decision \\
\hline 8 & Provision of training allowance for educators & 3.73 & 0.84 & VHE \\
\hline 9 & Adequate fund for TVET training resources by government & 2.80 & 0.66 & HE \\
\hline 10 & Provision of starter pack after training in TVET & 3.69 & 0.53 & VHE \\
\hline 11 & Provision of allowances for trainers & 2.58 & 0.54 & HE \\
\hline 12 & Motivation of TVET educators by government & 3.51 & 0.67 & VHE \\
\hline 13 & Credit loan facilities to TVET trainees to practice TVET trades & 2.74 & 0.88 & HE \\
\hline 14 & Motivation of TVET educators by NGOs & 3.03 & 1.03 & HE \\
\hline 15 & High remuneration for VTE educators & 3.55 & 0.64 & VHE \\
\hline 16 & Adequate Financing for TVET trades & 3.71 & 1.03 & VHE \\
\hline & Average Mean/SD & $\mathbf{3 . 2 6}$ & $\mathbf{0 . 7 6}$ & HE \\
\hline
\end{tabular}

Source: Researchers Field Work; 2018

Table 2 revealed the extent to which provision of fund aid in revamping TVET programmes. Items8, 10, 12, 15 and 16 were seen to revamp TVET to Very High Extent while items 9, 11, 13 and 14 were seen to be at High Extent. On the average, funding to revamp TVET programmes was rated High Extent (HE) with a mean of 3.26. The standard deviations for the items are within the range of 0.53 1.03 , indicating that the respondents were close to each other in their opinions. 
Revamping Technical and Vocational Education and Training in Niger Delta for Sustainable Development

Research Question3: To what extent can curriculum aid in revamping vocational and technical education programme in Niger Delta?

Table3.Mean Response on the Provision of Curriculum in Revamping TVET

\begin{tabular}{|l|l|l|l|l|}
\hline S/NO & Item Statement & Mean & S.D & Decision \\
\hline 17 & Regular review of TVET curriculum & 3.90 & 0.83 & VHE \\
\hline 18 & Assessment of TVET curriculum & 3.59 & 0.93 & VHE \\
\hline 19 & Pedagogical skills of TVET teachers & 3.42 & 0.72 & HE \\
\hline 20 & Presence of experience TVET teachers & 3.34 & 0.79 & HE \\
\hline 21 & Teachers positive attitude towards new curriculum & 3.68 & 0.62 & VHE \\
\hline 22 & Provision of flexible curriculum & 3.77 & 0.85 & HE \\
\hline 23 & Ease with new curriculum implementation & 3.41 & 0.75 & HE \\
\hline & Average Mean/SD & $\mathbf{3 . 5 9}$ & $\mathbf{0 . 7 8}$ & HE \\
\hline
\end{tabular}

Source: Researchers Field Work; 2018

Table 3 revealed the extent to which curriculum aid in revamping VTE programmes. Item 17, 18 and 21 were seen to revamp VTE to Very High Extent while item 19, 20, 22 and 23 were seen to be at High Extent. The standard deviations for the items are within the range of $0.62-0.93$, implying that the respondents are homogeneous in their opinions.

\section{DISCUSSION OF FINDINGS}

The result in Table 1 revealed that provision of adequate modern facilities will revamped VTE programmes for sustainable development in Niger Delta through the provision of e-library, availability of workshops, rehabilitation of workshops, availability of personal computers etc. These findings are consistent with the observation of Deebom and Zite (2016) that utilization of facilities like internet and web browsing, e-library, availability of personal computers etc by teachers and students enhances students' academic performance in secondary school.

The result in Table 2 revealed that VTE programmes will be revamped in Niger Delta for sustainable development through provision of training allowance, government motivating VTE educators, adequate financing, high remuneration of VTE educators etc. These finding is line with Okwelle and Deebom (2017) who found that remuneration of vocational teachers, adequate financing, adequate training facilities are strategies for improving TVET implementation for sustainable development in Niger Delta geopolitical area. Also, the poor funding status of TVET is decried by Okwelle and Wordu (2016) who reported that sufficient fund for TVET in the country are not provided either by the government or the private sector.

The result in Table 3 revealed that VTE programmes can be revamped in Niger Delta for sustainable development through regular review and assessment of TVET curriculum. These finding is line with Uddin (2013) who stressed that assessment and review of VTE curriculum are strategies for making VTE programmes viable in Nigeria.

\section{CONCLUSION}

This paper investigated revamping vocational and technical education in Niger Delta for sustainable development. Based on this intent, relevant literature was explored for deeper insight on the potentials of revamping vocational and technical education and associated sustainable development. The general finding from the respondents indicated that TVET could only be revamped if there is improvement on dilapidated infrastructure in the institution of learning, appropriate utilization of funds allocated to TVET at various levels of education, flexible curriculum etc. Finally, Vocational and technical education revamping, if vigorously pursued would enhanced speedy diversification of our economy which would enhance the actualization of the Millennium Development Goals (MDGS) and Vision 20:2020 for sustainable development of Nigeria.

\section{RECOMMENDATION}

For vocational and technical education to be more impactful on employability and sustainable development, the under-listed recommendations are proposed for implementation by the policymakers and stakeholders:

i. The ministries of education in all states of Niger Delta should improve the standard of infrastructure in all the technical colleges in order to revamp vocational and technical education programmes Nigeria. 
ii. The Government through the ministry of education in Niger Delta states should provide modern workshop facilities in all the technical colleges in order to improve the quality of all vocational and technical education programmes.

iii. With regards to funding for vocational and technical education, the Niger Delta State Governments and other stakeholders should provide adequate funding for vocational and technical education in their annual budgets in order to enhance the capacity of technical education programmes to meeting individual, group and national aspirations.

iv. With growth in the number of formal and informal vocational and technical education institutions in Nigeria, there is an urgent need for constant review and assessment of TVET curriculum in states of Niger Delta to ensure viable TVET delivery.

\section{REFERENCES}

[1] Adebola, H.E (2007). Standard in mass literacy. Adult and non-formal educatoin. Capacity building and sustainable development in Nigeria. UNIZIK Orient Journal of Education. 3(1).129-133.

[2] Ayodele, J.B. (2006). Obstacle to entrepreneurship development in Nigeria. In F. Omotosho, T.K.O. Aluko, O.I. Wale-Awe, and G. Adaramola (eds). Introduction to entrepreneurship development in Nigeria. Ado-Ekiti: UNAD press.

[3] Badawi, A, A. (2013) TVET and entrepreneurship skills (Chapter 8). In Revisiting global trends in TVET: Reflections on theory and practice. UNESCO-UNEVOC International Centre for Technical and Vocational Education and Training. Available: http://www.unevoc.unesco.org/fileadmin/up/ 2013_epub_revisiting_global_trends_in_tvet_book.pdf (Accessed: 14 September, 2013).

[4] Career and Technical Education (CTE) (2009). Washington office of superintendent of public instruction. http://www.k12.wa.us/careerTedEd/.

[5] Deebom, M. T. \&Zite, B. N. (2016). Effectiveness of Information Communication Technology (ICT) in Teaching and Learning in Public Senior Secondary Schools in Ogoni Area, Rivers State. International Journal of Education and Evaluation 2 (4): 18-26.

[6] Maclean, R., (2011) Key Issues and Research Challenges for TVET: Bridging the gap between TVET research and the needs of policy makers', in NORRAG NEWS, Towards a New Global World of Skills Development? TVET's turn to Make its Mark, No.46, September 2011, pp. 125-127

[7] May, I.A. (2007). Assessing the realities and challenges of technical education in Imo state secondary school education system in Nigeria. Journal of educational administration and planning. (7), March

[8] National Policy on Education (2013) Federal Government of Nigeria, Lagos: NERDC Press.

[9] Nwanaka, C.R. \&Amaefule, S. (2011) Skills acquisition: Imperative for business studies among secondary schools in Rivers State, Mediterranean Journal of social sciences, 2(7), 123-134

[10] Oguntuyi, A.N. (2013). A viable vocational technical education curriculum: A tool for economic and technology development in Nigeria, Scholarly Journal of Education, 2(2), 22-26

[11] Okolocha, C. C. (2012) Vocational technical education in Nigeria: Challenges and the way forward. Business Management Dynamics,.2 (6),1-8.

[12] Okwelle, P. C. \&Deebom, M. T. (2017). Technical vocational education and training as a tool for sustainable empowerment of youths in niger delta, Nigeria. International Journal of Innovative Social \&Science Education Research 5(1), 29-38.

[13] Okwelle, P. C. \&Wordu, C. C. (2016). Attitudes of private sectors towards funding of technical vocational education and training (TVET) programmes in Rivers State. African Journal of Vocational Education, $5(1), 82-87$.

[14] Uddin, P. S. O. (2013). Viable technical vocational education and training as ameans of employment generation for the Nigeria youths. Research Journal in Organizational Psychology \& Educational Studies, 2(6) 296-302.

[15] Ugoh, S.C. (2008). Oil politics and crisis of development on the Niger Delta. Journal of sustainable development in Africa. 10(2)91 -115.

Citation: Zite, BaridoolenuNgor, Okwelle, P. Chijioke. "Revamping Technical and Vocational Education and Training in Niger Delta for Sustainable Development". International Journal of Humanities Social Sciences and Education (IJHSSE), vol 5, no. 3, 2018, pp. 91-95 doi: http://dx.doi.org/10.20431/2349-0381.0503009.

Copyright: (C) 2018 Authors. This is an open-access article distributed under the terms of the Creative Commons Attribution License, which permits unrestricted use, distribution, and reproduction in any medium, provided the original author and source are credited. 